\title{
Risk Characterization Data Manual for Category D Inactive Liquid Low-Level Waste Tank Systems at Oak Ridge National Laboratory, Oak Ridge, Tennessee
}
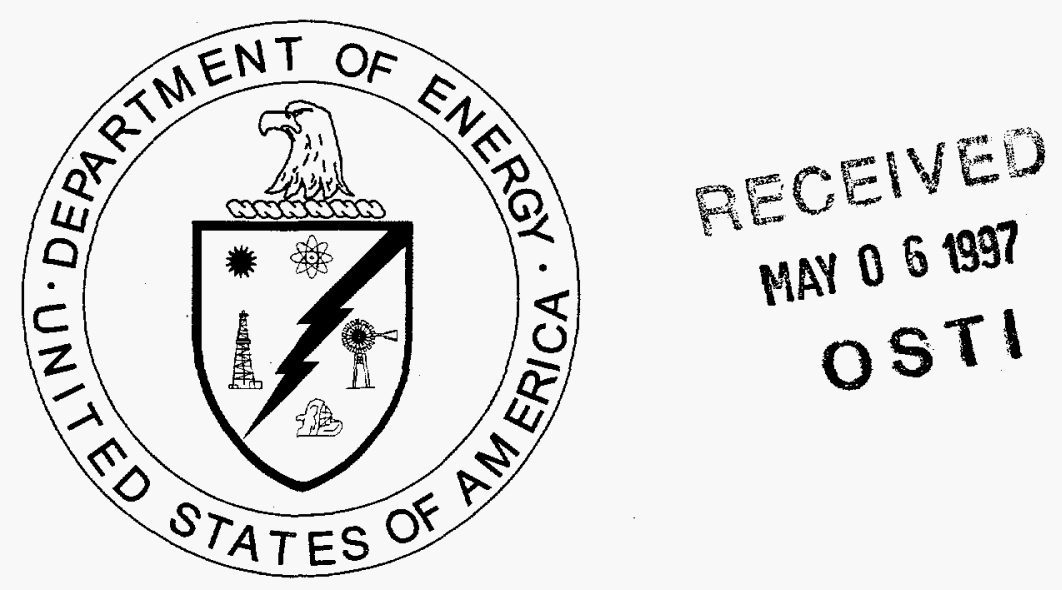

This document has been approved by the ORNL Plant Technical Information Office for release to the public. Date: $4 / 23 / 97$

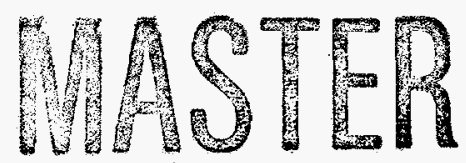




\section{H\&R Technical Associates, Inc.}

contributed to the preparation of this document and should not be considered an eligible contractor for its review. 


\section{DISCLAIMER}

This report was prepared as an account of work sponsored by an agency of the United States Government. Neither the United States Government nor any agency thereof, nor any of their employees, make any warranty, express or implied, or assumes any legal liability or responsibility for the accuracy, completeness, or usefulness of any information, apparatus, product, or process disclosed, or represents that its use would not infringe privately owned rights. Reference herein to any specific commercial product, process, or service by trade name, trademark, manufacturer, or otherwise does not necessarily constitute or imply its endorsement, recommendation, or favoring by the United States Government or any agency thereof. The views and opinions of authors expressed herein do not necessarily state or reflect those of the United States Government or any agency thereof. 


\section{DISCLAMMIER}

Portions of this document may be illegible in electronic image products. Images are produced from the best available original document. 
Energy Systems Environmental Restoration Program

Risk Characterization Data Manual for Category D

Inactive Liquid Low-Level Waste Tank Systems at Oak Ridge National Laboratory, Oak Ridge, Tennessee

Date Issued-April 1997

\author{
Prepared by \\ Risk Analysis Section \\ Health and Safety Research Division \\ Oak Ridge National Laboratory \\ Prepared for the \\ U.S. Department of Energy \\ Office of Environmental Management \\ under budget and reporting code EW 20 \\ Environmental Management Activities at \\ OAK RIDGE NATIONAL LABORATORY \\ Oak Ridge, Tennessee 37831 \\ managed by \\ LOCKHEED MARTIN ENERGY SYSTEMS, INC. \\ for the \\ U.S. DEPARTMENT OF ENERGY \\ under contract DE-AC05-84OR21400
}




\section{CONTENTS}

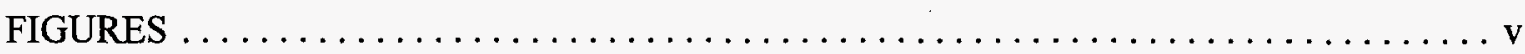

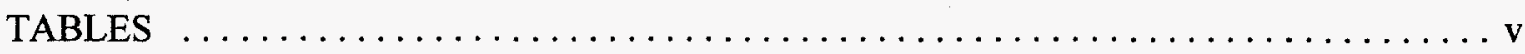

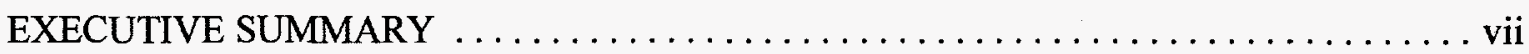

1. INTRODUCTION $\ldots \ldots \ldots \ldots \ldots \ldots \ldots \ldots \ldots \ldots \ldots \ldots \ldots \ldots \ldots \ldots \ldots, 1-1$

1.1 BACKGROUND $\ldots \ldots \ldots \ldots \ldots \ldots \ldots \ldots \ldots \ldots \ldots \ldots \ldots \ldots, 1-1$

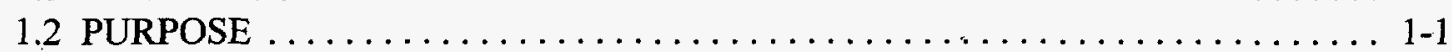

1.3 SCOPE $\ldots \ldots \ldots \ldots \ldots \ldots \ldots \ldots \ldots \ldots \ldots \ldots \ldots \ldots \ldots \ldots \ldots \ldots \ldots \ldots \ldots, 1$

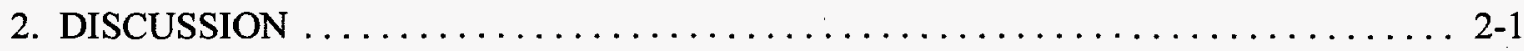

2.1 METHODOLOGY $\ldots \ldots \ldots \ldots \ldots \ldots \ldots \ldots \ldots \ldots \ldots \ldots \ldots \ldots \ldots \ldots \ldots \ldots \ldots \ldots, 1$

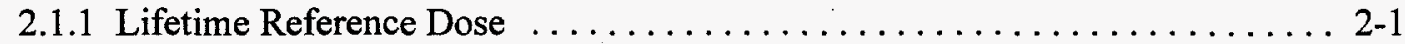

2.1.2 Reference Volume $\ldots \ldots \ldots \ldots \ldots \ldots \ldots \ldots \ldots \ldots \ldots \ldots \ldots \ldots \ldots \ldots \ldots \ldots \ldots \ldots \ldots, 2-2$

2.1.3 Toxic Index $\ldots \ldots \ldots \ldots \ldots \ldots \ldots \ldots \ldots \ldots \ldots \ldots \ldots \ldots \ldots \ldots \ldots, 2-2$

2.2 RISK SCORING PROCESS $\ldots \ldots \ldots \ldots \ldots \ldots \ldots \ldots \ldots \ldots \ldots \ldots \ldots \ldots \ldots \ldots, 2-3$

2.2.1 Leak Characteristics $\ldots \ldots \ldots \ldots \ldots \ldots \ldots \ldots \ldots \ldots \ldots \ldots \ldots, 2-3$

2.2.2 Location $\ldots \ldots \ldots \ldots \ldots \ldots \ldots \ldots \ldots \ldots \ldots \ldots \ldots \ldots \ldots \ldots, 2-3$

2.2.3 Toxic Potential $\ldots \ldots \ldots \ldots \ldots \ldots \ldots \ldots \ldots \ldots \ldots \ldots \ldots \ldots \ldots \ldots \ldots \ldots \ldots \ldots, 4$

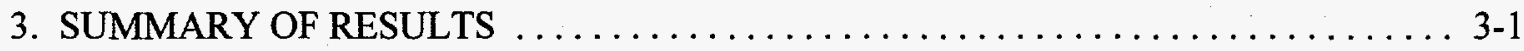

4. RISK CHARACTERIZATION RESULTS $\ldots \ldots \ldots \ldots \ldots \ldots \ldots \ldots \ldots \ldots \ldots, 4,1$

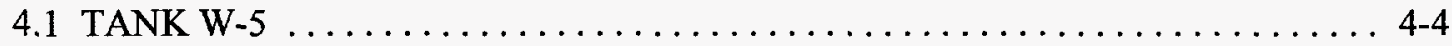

4.2 TANK $W-6 \ldots \ldots \ldots \ldots \ldots \ldots \ldots \ldots \ldots \ldots \ldots \ldots \ldots \ldots \ldots \ldots \ldots, 4,5$

4.3 TANK $W-7 \ldots \ldots \ldots \ldots \ldots \ldots \ldots \ldots \ldots \ldots \ldots \ldots \ldots \ldots \ldots, 4,6$

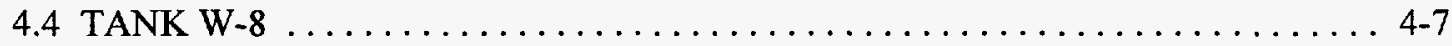

4.5 TANK W-9 $\ldots \ldots \ldots \ldots \ldots \ldots \ldots \ldots \ldots \ldots \ldots \ldots \ldots \ldots \ldots \ldots, 4,8$

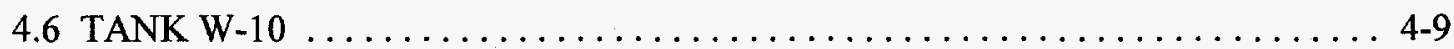

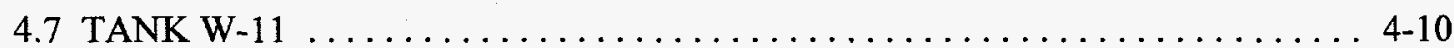

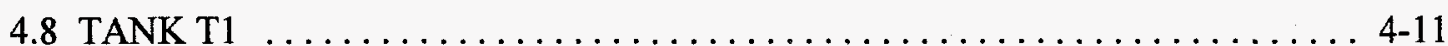

4.9 TANK T2 $\ldots \ldots \ldots \ldots \ldots \ldots \ldots \ldots \ldots \ldots \ldots \ldots \ldots \ldots, \ldots \ldots \ldots, \ldots, 12$

4.10 TANK T3 $\ldots \ldots \ldots \ldots \ldots \ldots \ldots \ldots \ldots \ldots \ldots \ldots \ldots \ldots \ldots \ldots \ldots, 4,13$

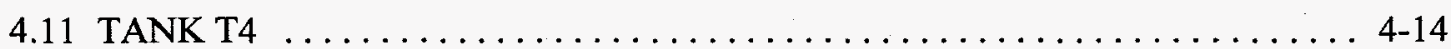

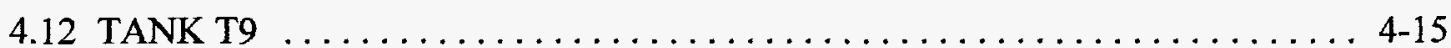

4.13 TANK TH-1 $\ldots \ldots \ldots \ldots \ldots \ldots \ldots \ldots \ldots \ldots \ldots \ldots \ldots \ldots \ldots, 4,16$

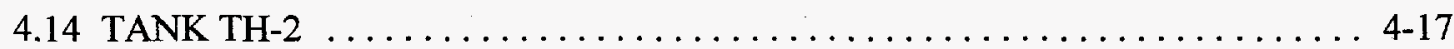

4.15 TANK TH-3 $\ldots \ldots \ldots \ldots \ldots \ldots \ldots \ldots \ldots \ldots \ldots \ldots \ldots \ldots \ldots \ldots \ldots \ldots \ldots \ldots, 18$

4.16 TANK TH-4 $\ldots \ldots \ldots \ldots \ldots \ldots \ldots \ldots \ldots \ldots \ldots \ldots \ldots \ldots \ldots \ldots \ldots, 4,19$

4.17 TANK WC-1 $\ldots \ldots \ldots \ldots \ldots \ldots \ldots \ldots \ldots \ldots \ldots \ldots \ldots \ldots \ldots \ldots, 4-20$

4.18 TANK WC-15 $\ldots \ldots \ldots \ldots \ldots \ldots \ldots \ldots \ldots \ldots \ldots \ldots \ldots \ldots \ldots, 4-21$

4.19 TANK WC-17 $\ldots \ldots \ldots \ldots \ldots \ldots \ldots \ldots \ldots \ldots \ldots \ldots \ldots \ldots \ldots \ldots \ldots, 22$

4.20 TANK $W-1 \ldots \ldots \ldots \ldots \ldots \ldots \ldots \ldots \ldots \ldots \ldots \ldots \ldots \ldots \ldots \ldots, 4-23$

4.21 TANK W-1A $\ldots \ldots \ldots \ldots \ldots \ldots \ldots \ldots \ldots \ldots \ldots \ldots, 4,24$

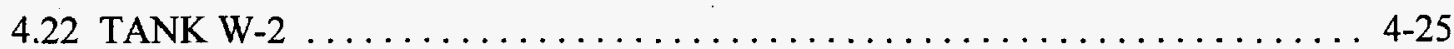

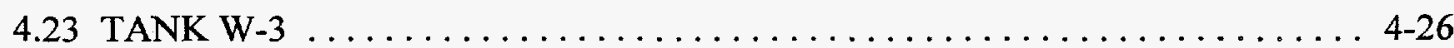

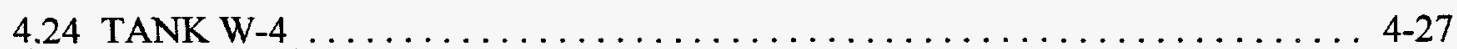




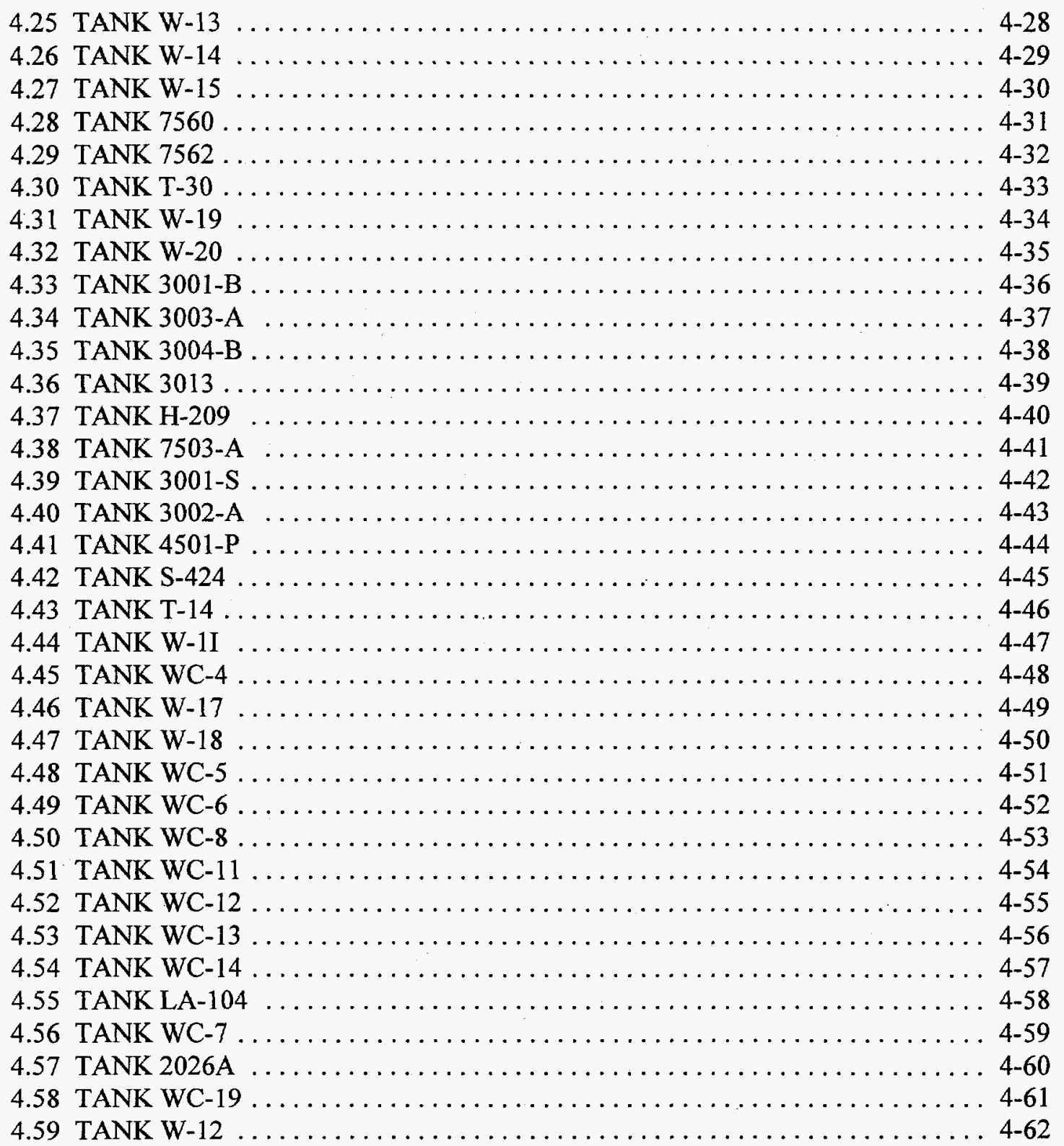

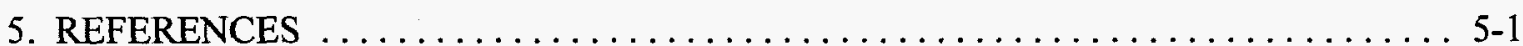




\section{FIGURES}

1.1 Location of inactive LLLW tanks in the Bethel Valley (main laboratory) area . . . . 1-2

1.2 Location of inactive LLLW tanks in the Melton Valley area

\section{TABLES}

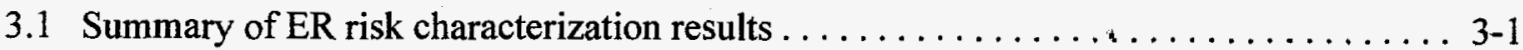

3.2 Summary of WM risk characterization results $\ldots \ldots \ldots \ldots \ldots \ldots \ldots \ldots \ldots \ldots \ldots \ldots \ldots \ldots, 2$

4.1 Alphanumeric cross-reference of LLLW storage tanks . . . . . . . . . . . 4-2 


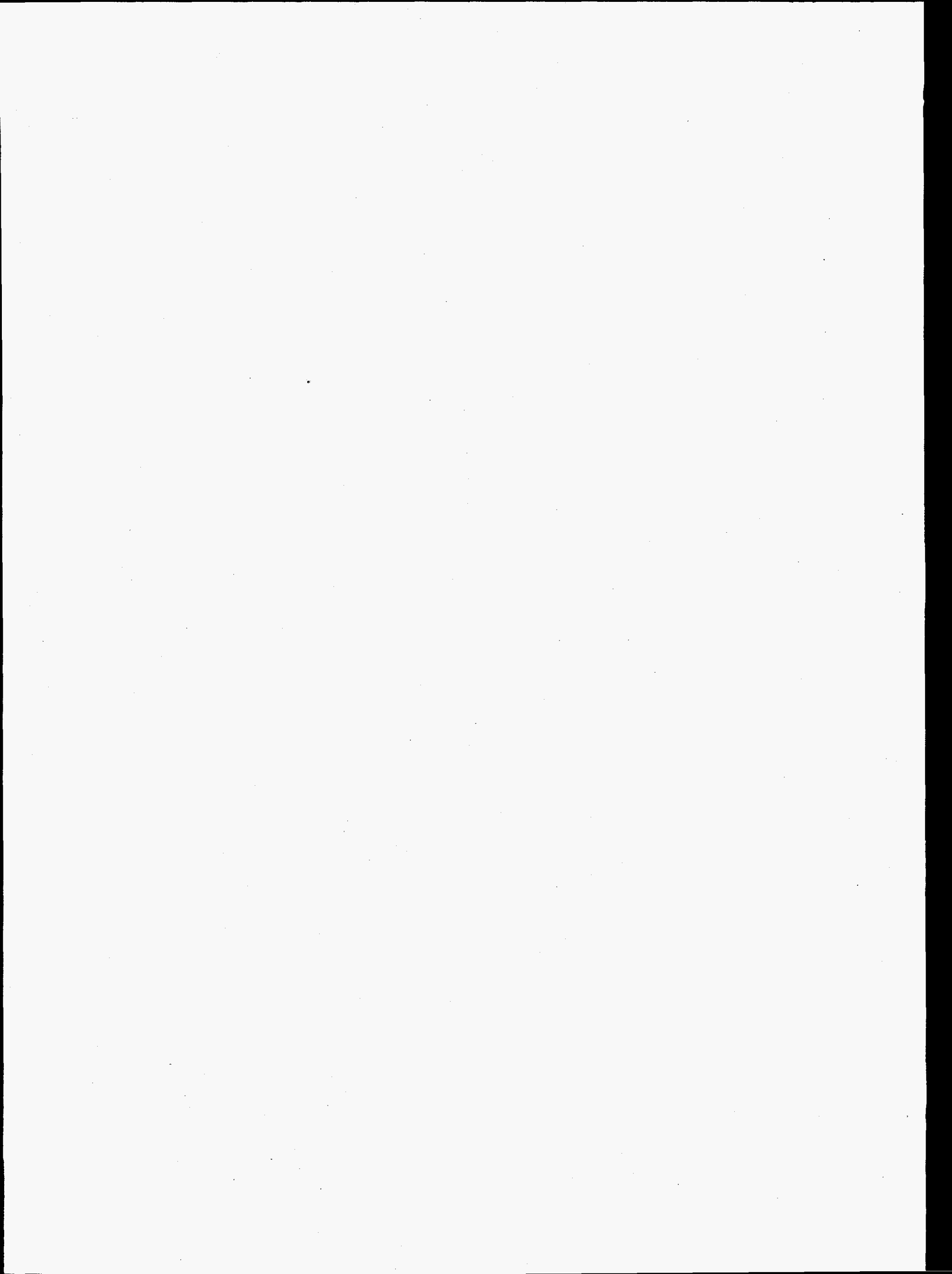




\section{EXECUTIVE SUMMARY}

This manual reports the results of a risk characterization of Category D inactive liquid low-level radioactive waste (LLLW) at the Oak Ridge National Laboratory (ORNL). The risk characterization is required by the Federal Facility Agreement between the Department of Energy-Oak Ridge Operations Office, the Environmental Protection Agency-Region IV, and the Tennessee Department of Environment and Conservation. The intent of the risk characterization is to determine relative priorities for assessment and remediation.

Most of the LLLW tanks discussed in this manual have been sampled for preliminary characterization. Several of the tanks were found to be empty and one tank (3001-S) was found not to exist. Each sampled tank was scored on a scale of 1 to 5 on the basis of three criteria: (1) leak characteristics, (2) location, and (3) toxicological characteristics of residual sludges and liquids. Each criterion was assigned a weighting factor based on perceived importance. The criterion score multiplied by the weighting factor equaled the tank's total score for that criterion. The three weighted criterion scores for each tank were then summed for a total score for that tank.

When the scores for all tanks had been weighted and summed, the tanks were ranked in descending order on the basis of their total scores. The highest possible score for a tank is 30 . The descending order represents the recommended priorities for evaluation: the higher the score, the higher the priority for evaluation. 


\section{INTRODUCTION}

\subsection{BACKGROUND}

Oak Ridge National Laboratory (ORNL) is a multidisciplinary research facility that began operation in 1943 as part of the Manhattan Project. The original missions of the Laboratory were to develop a prototypic graphite reactor and to reprocess the reactor fuel for plutonium recovery. After World II, the primary functions of ORNL were fuel reprocessing research; radioisotopes production and applications development; and development, testing, and operation of nuclear reactor concepts. More recently, the Laboratory has increased its role in biological, environmental, energy, and materials research. As a consequence of these multidisciplinary research activities, heterogeneous waste has been generated in varying amounts over time, including solid and liquid radioactive, hazardous, and mixed wastes.

Most of the system to handle the liquid low-level radioactive waste (LLLW) was installed more than 30 years ago. The initial system and its subsequent modifications were designed to minimize radiation exposure to LLLW system users and operators. The system includes features such as unvalved gravity-drained transfer lines to prevent waste backup into generator areas and provisions for remote operations to minimize personnel exposure. Over the years, tank systems were abandoned as their integrity was breached or as programs were terminated. Some of the tanks were removed from service with no intended future use. These tanks are classified as Category D tanks per the Federal Facility Agreement (FFA). As-built drawings for most of the tank systems do not exist. The inactive portion of the system consists almost entirely of tanks without secondary containment.

Existing waste and risk characterization information and the results of completed investigations on these Category D tank systems have been organized into two data manuals: a Waste Characterization Data Manual and a Risk Characterization Data Manual. The Waste Characterization Data Manual contains the results of an analysis of the contents of the LLLW tanks that have been removed from service in accordance with the requirements of the ORNL FFA. This Risk Characterization Data Manual contains the risk characterization information for the Category D tanks.

\subsection{PURPOSE}

Subsection IX.G.2 of the FFA between the Department of Energy-Oak Ridge Operations Office, the Environmental Protection Agency-Region IV, and the Tennessee Department of Environment and Conservation requires risk characterizations for Category D tanks. These risk characterizations must describe and define categories of risk for all systems pending final remediation. The purpose of the risk characterization is not to determine a detailed assessment of risks for each tank system but to establish a ranking that can be used to determine relative priorities for assessment and remediation.

\subsection{SCOPE}

This manual reports the results of a risk-based analysis ${ }^{1}$ to prioritize the inactive LLLW tanks for further evaluation. Category $D$ tanks are those that are designated as removed from service and have no intended future use. The locations of the inactive tanks are shown in Figs. 1.1 and 1.2. All 


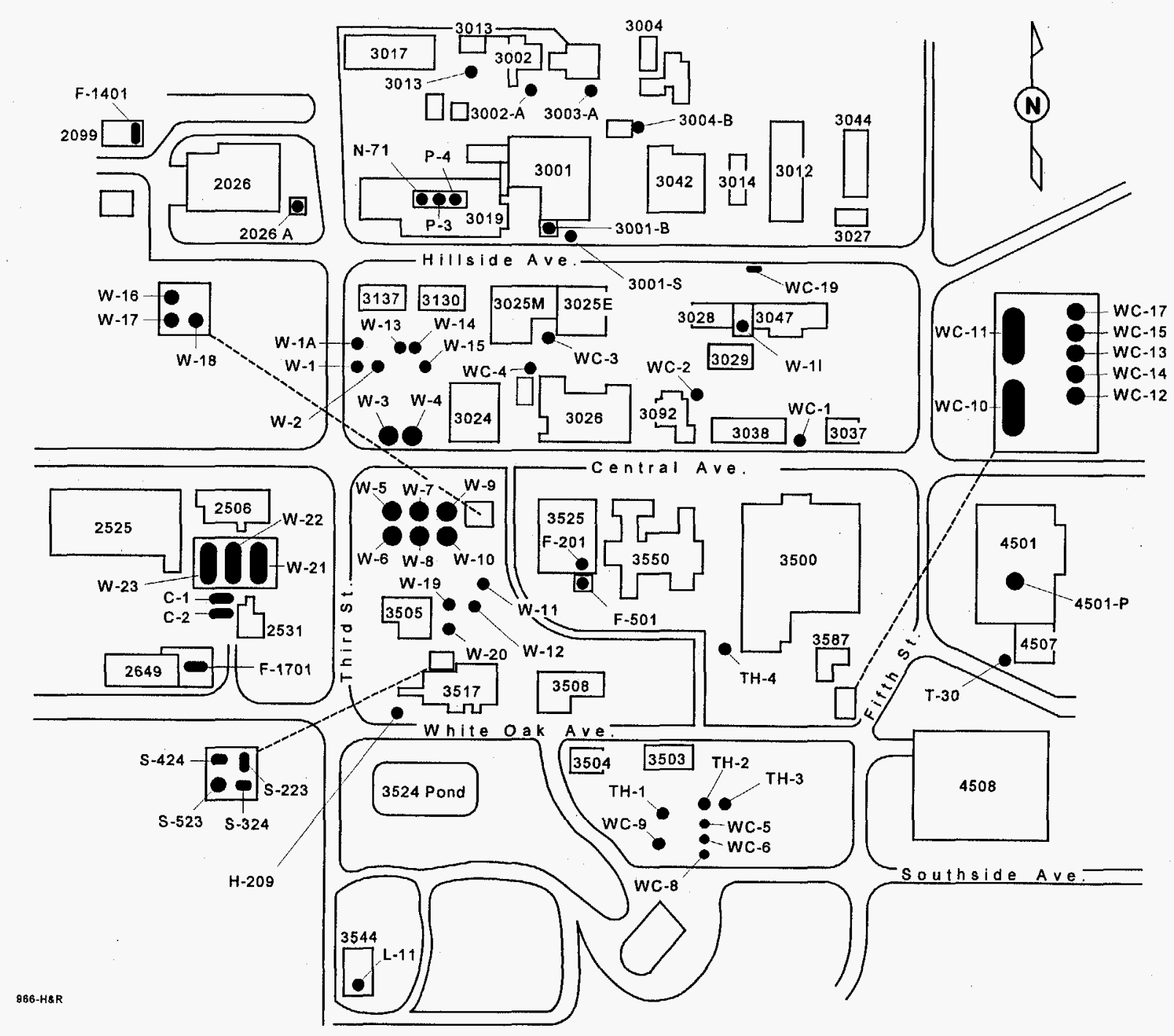

Fig. 1.1. Location of inactive LLLW tanks in the Bethel Valley (main laboratory) area. 


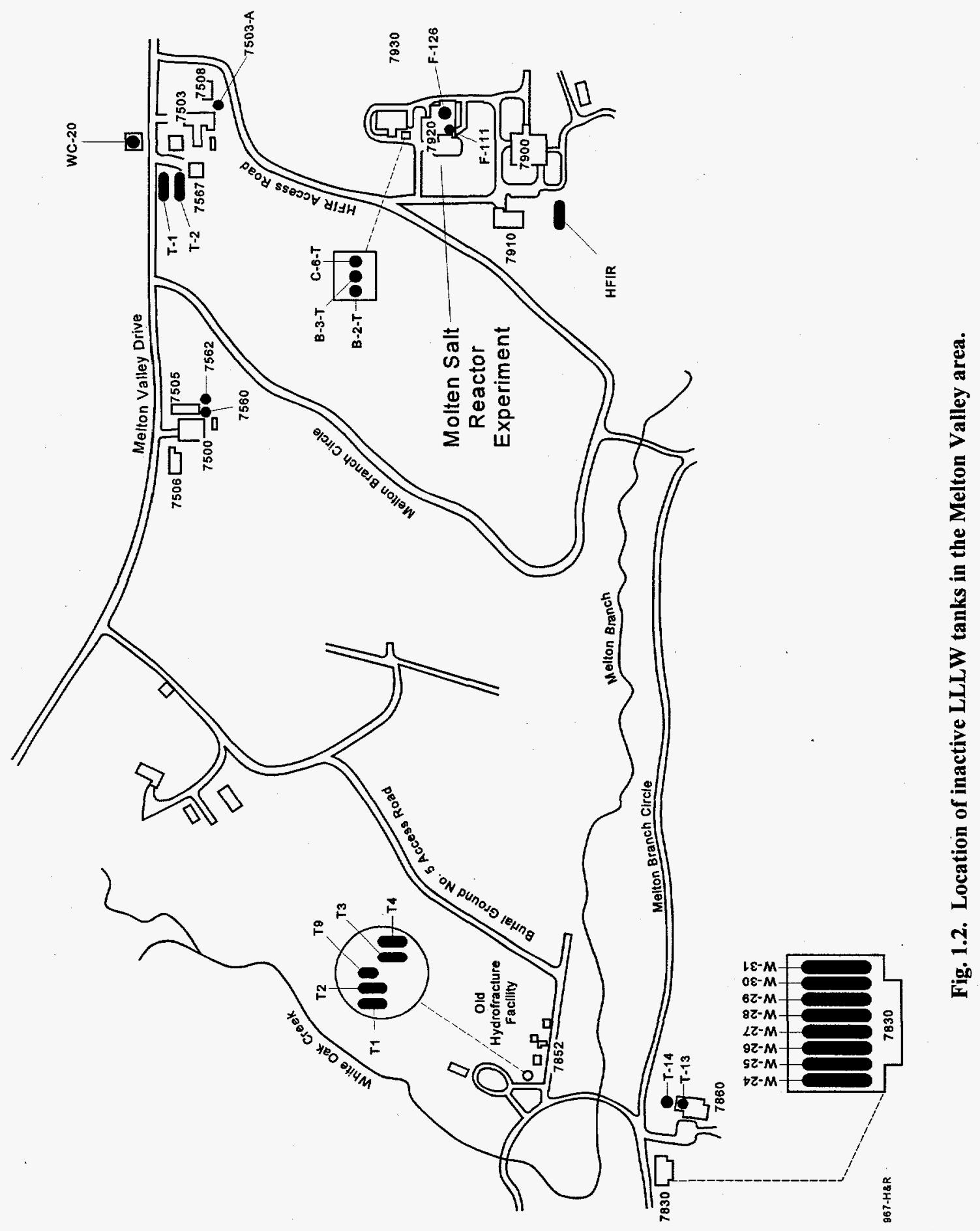


Category D tanks that have been accepted into the Environmental Restoration (ER) Program at ORNL have been assessed for preliminary characterization. During the course of the preliminary characterization, several tanks were determined to be empty and one tank (3001-S) was determined to not exist. A field investigation was unable to verify the tank's existence, which had been postulated based on the existence of some design drawings of the tank.

Other tanks listed in this manual are in the Waste Management (WM) Program. Sampling data have been compiled for those WM tanks that were found to contain liquid.

A risk-based method was used to prioritize the tanks and is discussed in Sect. 2. 


\section{DISCUSSION}

\subsection{METHODOLOGY}

The risk-based approach used to prioritize the Category D LLLW tanks for further evaluation is based on three major criteria: (1) leak characteristics of the tanks, (2) location of the tanks, and (3) toxicological characteristics of constituents in the tanks. These three criteria are discussed in this section. Tank-specific data concerning the leak characteristics are found in the leak-test data manual. ${ }^{4}$ Information on the structural material, location, and tank contents is contained in the waste characterization data manual. ${ }^{5}$ Further detail on the contents of recently sampled Category D tanks can be found in two sampling and analysis reports. ${ }^{2,3}$ The risk-based methodology is described in greater detail in the report on a risk-based approach to prioritize Category D LLLW storage tanks for further evaluation of interim corrective measures. ${ }^{1}$

1. Leak characteristics. Leak characteristics of the Category D LLLW tanks help establish the likelihood and extent of contaminant migration to the environment. A leak is defined as the escape of contents from either primary or secondary containment. For Category D LLLW tanks currently known to leak, the criterion was based on the quantity or degree of leakage (as determined from the leak data); for tanks with no leak data, the criterion was based on the structural material of the tank. For example, tanks constructed of porous concrete or a mild steel susceptible to corrosion are more likely to leak than tanks constructed of stainless steel.

2. Location. The location of the Category D LLLW tanks further affects the likelihood and the extent of contaminant migration to the environment. The location criterion is site specific; it is based on the proximity of the tank to groundwater and surface water and on the characteristics of the soil surrounding the tank. For the ORNL site, this criterion is based primarily on the proximity of the LLLW tanks to surface water.

3. Toxicological characteristics. Toxicological characteristics of constituents detected in the residual liquids of the tanks help establish the potential for adverse impact of contaminant migration on the environment, the food chain, and human health. Although the tanks contain residual liquid waste and sludge, only the toxicological characteristics of liquid wastes are considered because of their greater tendency for mobility and migration from leaking tanks. Constituents of concern identified in the liquid phase in the Category D LLLW tanks are ${ }^{90} \mathrm{Sr}$, ${ }^{137} \mathrm{Cs},{ }^{238} \mathrm{U},{ }^{238} \mathrm{Pu},{ }^{239} \mathrm{Pu},{ }^{241} \mathrm{Am},{ }^{244} \mathrm{Cm},{ }^{60} \mathrm{Co},{ }^{192} \mathrm{Ir}$, carbon tetrachloride, trichloroethene, tetrachloroethane, methyl ethyl ketone, mercury, lead, and chromium.

Three factors are considered in establishing the toxicological characteristics of the LLLW tanks: (1) the toxicity of contaminants as determined by the reference dose (RfD) for noncarcinogenic chemicals, the cancer potency factor (CPF) for nonradioactive carcinogens, and the cancer slope factor (CSF) for radionuclides; (2) the concentration of the contaminants of concern in the liquid; and (3) the liquid volume in each tank. These factors are combined into a single dimensionless number called the toxic index (TI). The steps necessary to calculate the TI for an Category D LLLW tank follow.

\subsubsection{Lifetime Reference Dose}

RfDs for noncarcinogenic chemicals, CPFs for nonradioactive carcinogenic chemicals, and CSFs for radionuclides are converted into lifetime RfDs. Standard default exposure and risk factors issued by the EPA are used to determine lifetime RfDs. 
Noncarcinogenic Chemicals. For noncarcinogenic chemicals, a lifetime RfD (milligrams) is the total amount of intake at the RfD for 70 years. Lifetime $\mathrm{RfD}$ is a product of the RfD (milligrams per kilogram per day), the reference body weight $(70 \mathrm{~kg})$, and the average lifetime exposure (70 years).

$$
\text { lifetime } \operatorname{RfD}(\mathrm{mg})=\mathrm{RfD}(\mathrm{mg} / \mathrm{kg} / \mathrm{d}) \times 70(\mathrm{~kg}) \times 70(\text { years }) \times 365(\mathrm{~d} / \text { year })
$$

Nonradioactive Carcinogenic Chemicals. For nonradioactive carcinogenic chemicals, a lifetime RfD (milligrams) is the total dose a person receives over a lifetime of 70 years if that person takes in a daily dose equivalent to the $10^{-6}$ lifetime risk level. Lifetime RfD is a product of lifetime cancer risk $\left(10^{-6}\right)$, reference body weight $(70 \mathrm{~kg})$, and average lifetime exposure (70 years), divided by the oral CPF.

$$
\text { lifetime } \operatorname{RfD}(\mathrm{mg})=\frac{10^{-6} \times 70(\mathrm{~kg}) \times 70(\text { years }) \times 365(\mathrm{~d} / \text { year })}{\mathrm{CPF}(\mathrm{mg} / \mathrm{kg} / \mathrm{d})^{-1}}
$$

Radionuclides. For radionuclides, a lifetime $\mathrm{RfD}$ (picocuries) is the total amount of radioactivity a person takes in if total exposure over a lifetime produces a $10^{-6}$ lifetime risk level. Lifetime RfDs are derived by dividing the $10^{-6}$ risk level by the ingestion CSFs (in $\mathrm{pCi}^{-1}$ ).

$$
\text { lifetime } \mathrm{RfD}(\mathrm{pCi})=\frac{10^{-6}}{\mathrm{CSF}\left(\mathrm{pCi}^{-1}\right)}
$$

\subsubsection{Reference Volume}

Reference volume is the volume of a contaminant-containing liquid that a person must ingest to receive a lifetime RfD. To define the reference volume in an Category D LLLW tank, a contaminant's lifetime RfD is divided by its highest concentration detected in the liquid.

$$
\text { reference volume }=\frac{\text { lifetime } \mathrm{RfD} \text { for contaminant }}{\text { contaminant concentration }}
$$

Concentrations for noncarcinogenic and carcinogenic chemicals are expressed in milligrams per liter. Concentrations for radionuclides are expressed in picocuries per liter. Reference volumes are computed for each contaminant of concern in an Category D LLLW tank. The resultant reference volumes for carcinogens are calculated separately ${ }^{1}$ and presented as follows:

$$
\begin{aligned}
& \mathrm{CRV}=\left(\sum 1 / \mathrm{V}_{\mathrm{i}}\right)^{-1} \\
& \mathrm{NRV}=\left(\sum 1 / \mathrm{V}_{\mathrm{i}}\right)^{-1}
\end{aligned}
$$

where CRV is the cancer reference volume, NRV is the noncancer reference volume, and $i$ is the identity of a particular contaminant. The lower of the two reference volumes is chosen as the representative reference volume for the particular tank.

\subsubsection{Toxic Index}

The $\mathrm{TI}$ is the number of reference volumes in the volume of residual liquid found in a tank. The TI considers both the toxicity of the contaminant and the volume of the contaminant in the liquid. To calculate the TI for an Category D LLLW tank, liquid volume (the volume of residual liquid in a tank, which is assumed to be constant over the period of sampling) is divided by the representative reference volume of the tank. 
toxic index $=\frac{\text { liquid volume }}{\text { reference volume }}$

A range of TIs will be developed and suitably divided to separate the tanks into distinct groups based on their individual TIs. To identify the range, the TIs for the individual tanks are calculated and arranged so that the high and low ends of the range can be identified. The range of TIs is then subdivided and assigned score values ranging from 1 to 5 .

\subsection{RISK SCORING PROCESS}

The three criteria (leak characteristics, location, and toxicological characteristics) are used to rank the Category D LLLW tanks with respect to potential adverse impact on the environment and human health. A numeric score from 0 to 5 is assigned to each of the three criteria; a score of 5 indicates highest priority. The sum of the scores for the three criteria is the score for a particular tank. The highest possible score for a tank is 30. The following site-specific criteria and tankspecific criteria are used to score the Category D LLLW tanks at ORNL.

\subsubsection{Leak Characteristics}

Category D LLLW tanks that are known to be leaking are scored higher than those with unknown leaking characteristics.

Leak characteristics

Major outleaker

Small outleaker

Inleaker

Inconclusive evidence

(a) concrete

(b) mild steel

(c) stainless steel

\section{$\underline{\text { Score }}$}

5

4

3

2

1

0

The term "outleaker" refers to those tanks that are leaking; "inleaker" refers to tanks that are accumulating fill from outside sources. The quantifiers "major" and "small" are based on the quantity of outleakage and on the toxicity of the tank's contents; it is usually a professional judgment.

The leak characteristics category carries a weight of 3 . The leak characteristic is considered the most important of the criteria because a leak must occur before any consequences will be experienced. A tank that is leaking, or is likely to leak, represents a greater risk than a stable, contained tank, even one that contains highly toxic material.

\subsubsection{Location}

Category D LLLW tanks located south of Central Avenue in the main plant area and near the Old Hydrofracture Facility are scored highest because of their proximity to White Oak Creek and its tributaries. Other Category D LLLW tanks are considered to be relatively distant from surface water bodies [tanks to the north of Central Avenue and those near the Homogeneous Reactor Experiment (HRE)] or have their contents pumped directly into the active LLLW waste system (e.g., Tank W-1A). These tanks are therefore scored lower in the location category. 
Location

Score

Old Hydrofracture Facility Tanks

South of Central Avenue

5

North of Central Avenue

3

HRE Tanks

Pumped to active waste systems

0

The location category is considered the least important of the three criteria; therefore, it carries a weight of 1 .

\subsubsection{Toxic Potential}

Toxic potentials of the contents of the LLLW tanks are scored on the basis of their respective TIs developed for the risk characterization.' Scores are developed based only on liquids and do not consider sludge leaching. A screening of TIs indicated that the following ranking is suitable with respect to the toxic potential of tanks.

$\begin{array}{cc}\text { Toxic Index } & \text { Score } \\ & \\ >10^{10} & 5 \\ 10^{10} \text { to } 10^{8} & 4 \\ 10^{8} \text { to } 10^{6} & 3 \\ 10^{6} \text { to } 10^{4} & 2 \\ <10^{4} & 1 \\ \text { empty tank } & 0\end{array}$

The toxic potential category carries a weight of 2 . Given that a leak has occurred, the second most important criterion is toxic potential. The release of a more toxic material is of more concern than the release of a less toxic material, even one close to on-site water bodies. 


\section{SUMMARY OF RESULTS}

In Tables 3.1 and 3.2, the ER and WM tanks are ranked in descending order based on their scores calculated in the risk-based prioritization report, respectively. ${ }^{1}$ Tanks that were not yet characterized as of 1997 are not listed in the following tables.

Table 3.1. Summary of ER risk characterization results

\begin{tabular}{lc}
\hline \multicolumn{1}{c}{ Tank } & Score \\
\hline W-7, W-8, W-10 & 22 \\
W-5, W-6, W-9 & 20 \\
W-3, W-4 & 19 \\
W-1A & 17 \\
W-11, T1, T2, T3, T4, T9, 7562* & 16 \\
TH-4, WC-17 & 15 \\
W-1, W-2 & 12 \\
3003-A & 10 \\
WC-15, T-30* & 7 \\
3013* & 6 \\
H-209* & 5 \\
3004-B* & 4 \\
TH-1, TH-2, TH-3, W-19, W-20 & 3 \\
WC-1, W-13, W-14, W-15, & 2 \\
3001-B* & 1 \\
7503-A, 7560 & \\
\hline
\end{tabular}

* These tanks have been removed or remediated. 
Table 3.2. Summary of WM risk characterization results

\begin{tabular}{lc}
\hline \multicolumn{1}{c}{ Tank } & Score \\
\hline WC-11, WC-12, WC-13, WC-14 & 18 \\
W-18 & 16 \\
2026A, WC-4 & 15 \\
WC-5*, WC-6*, WC-8* & 14 \\
3002-A, T-14, WC-19 & 11 \\
W-12 & 9 \\
4501-P*, S-424, W-17 & 3 \\
W-1I & 2 \\
\hline
\end{tabular}

* These tanks have been removed or remediated. 


\section{RISK CHARACTERIZATION RESULTS}

The following pages contain the results of the risk characterization of each tank. As the contents of additional tanks are sampled, a risk characterization will be performed and the results will be added to this data manual. If the tank is empty or scheduled to be emptied, no characterization of the toxicity will be performed; these tanks are documented in this data manual.

The tank risk characterization data summary sections are ordered in a manner convenient to implementation of the investigation programs, and the order remains consistent throughout all the data manuals. To assist the reader in locating a tank of interest, an alphanumeric listing of tanks is provided in Table 4.1 and cross-referenced to the section in which the results of the risk characterization for each tank appear. 
Table 4.1. Alphanumeric cross-reference of LLLW storage tanks

\begin{tabular}{|c|c|c|}
\hline Tank ID No. & $\begin{array}{l}\text { Section in data } \\
\text { manual }\end{array}$ & Data source \\
\hline LA-104* & 4.55 & Historical \\
\hline$S-424$ & 4.42 & DOE/OR-1135 \\
\hline $\mathrm{T} 1$ & 4.8 & ER-13 \\
\hline $\mathrm{T} 2$ & 4.9 & ER-13 \\
\hline T3 & 4.10 & ER-13 \\
\hline $\mathrm{T} 4$ & 4.11 & ER-13 \\
\hline T9 & 4.12 & ER-13 \\
\hline $\mathrm{T}-14$ & 4.43 & DOE/OR-1135 \\
\hline $\mathrm{T}-30^{*}$ & 4.30 & ER-13 \\
\hline TH-1 & 4.13 & DOE/OR-1138 \\
\hline TH-2 & 4.14 & DOE/OR-1138 \\
\hline TH-3 & 4.15 & DOE/OR-1138 \\
\hline TH-4 & 4.16 & ER-13 \\
\hline W-1 & 4.20 & ER-13 \\
\hline $\mathrm{W}-1 \mathrm{~A}$ & 4.21 & ER-13 \\
\hline W-1I & 4.44 & DOE/OR-1135 \\
\hline W-2 & 4.22 & ER-13 \\
\hline W-3 & 4.23 & ER-13 \\
\hline $\mathrm{W}-4$ & 4.24 & ER-13 \\
\hline W-5 & 4.1 & ER-13 \\
\hline W-6 & 4.2 & ER-13 \\
\hline W-7 & 4.3 & ER-13 \\
\hline W-8 & 4.4 & ER-13 \\
\hline W-9 & 4.5 & ER-13 \\
\hline W-10 & 4.6 & ER-13 \\
\hline W-11 & 4.7 & ER-13 \\
\hline$W-12$ & 4.59 & Historical \\
\hline $\mathrm{W}-13$ & 4.25 & DOE/OR-1138 \\
\hline W-14 & 4.26 & DOE/OR-1138 \\
\hline W-15 & 4.27 & DOE/OR-1138 \\
\hline W-17 & 4.46 & DOE/OR-1135 \\
\hline W-18 & 4.47 & DOE/OR-1135 \\
\hline$W-19$ & 4.31 & ER-13 \\
\hline W-20 & 4.32 & ER-13 \\
\hline
\end{tabular}


Table 4.1. Alphanumeric cross-reference of LLLW storage tanks

\begin{tabular}{lcc}
\multicolumn{3}{c}{ storage tanks } \\
\hline Tank ID No. & $\begin{array}{c}\text { Section in data } \\
\text { manual }\end{array}$ & Data source \\
\hline WC-1 & 4.17 & DOE/OR-1138 \\
WC-4 & 4.45 & DOE/OR-1135 \\
WC-5* & 4.48 & DOE/OR-1135 \\
WC-6* & 4.49 & DOE/OR-1135 \\
WC-7* & 4.56 & DOE/OR-1159 \\
WC-8* & 4.50 & DOE/OR-1135 \\
WC-11 & 4.51 & DOE/OR-1135 \\
WC-12 & 4.52 & DOE/OR-1135 \\
WC-13 & 4.53 & DOE/OR-1135 \\
WC-14 & 4.54 & DOE/OR-1135 \\
WC-15 & 4.18 & ER-19 \\
WC-17 & 4.19 & ER-13 \\
WC-19 & 4.58 & DOE/OR-1159 \\
$2026 A$ & 4.57 & DOE/OR-1159 \\
$3001-B^{*}$ & 4.33 & DOE/OR-1138 \\
$3001-S$ & 4.39 & DOE/OR-11597 \\
$3002-A$ & 4.40 & DOE/OR-1159 \\
$3003-A$ & 4.34 & DOE/OR-1159 \\
$3004-B^{*}$ & 4.35 & DOE/OR-1159 \\
$3013^{*}$ & 4.36 & DOE/OR-1159 \\
4501-P* & 4.41 & DOE/OR-1159 \\
$7503-A$ & 4.38 & DOE/OR-1159 \\
7560 & 4.28 & DOE/OR-1159 \\
H562 & 4.29 & DOE/OR-1159 \\
W- & 4.37 & DOE/OR-1159 \\
\hline
\end{tabular}

* These tanks have been removed or remediated. 


\subsection{TANK W-5}

Tank W-5 is a 170,000-gal. gunite tank located in the Bethel Valley South Tank Farm. The underground tank was constructed in 1943 for the storage of liquid low-level waste (LLLW).

Tank Risk Characterization Summary

Risk Characteristic

\section{Leaking Characteristics}

Inleaker

Location

South of Central Avenue

Toxicity

Primary Contaminants
${ }^{90} \mathrm{Sr}$
${ }^{137} \mathrm{Cs}$

TOTAL SCORE
$3(1)$

Score

4(2)

20

${ }^{1}$ Weighted score:

Leaking Characteristics carries a weight of 3

Location carries a weight of 1

Toxicity carries a weight of 2 


\subsection{TANK W-6}

Tank W-6 is a 170,000-gal. gunite tank located in the Bethel Valley South Tank Farm. The underground tank was constructed in 1943 for the storage of LLLW.

\section{Tank Risk Characterization Summary}

$\underline{\text { Risk Characteristic }}$

Leaking Characteristics

Inleaker

Location

South of Central Avenue

Toxicity $\frac{\text { Primary Contaminant }}{{ }^{137} \mathrm{Cs}}$
3(1)

\section{Score}

3(3)

4(2)

20

\footnotetext{
'Weighted score:

Leaking Characteristics carries a weight of 3

Location carries a weight of 1

Toxicity carries a weight of 2
} 


\subsection{TANK W-7}

Tank W-7 is a 170,000-gal. gunite tank located in the Bethel Valley South Tank Farm. The underground tank was constructed in 1943 for the storage of LLLW.

\section{Tank Risk Characterization Summary}

Risk Characteristic

Leaking Characteristics

Inleaker

Location

South of Central Avenue

Toxicity

$\frac{\text { Primary Contaminant }}{{ }^{137} \mathrm{Cs}}$

TOTAL SCORE ${ }^{1}$
3(3)

3(1)

$\underline{\text { Score }}$

$\mathbf{5}(2)$

22

\footnotetext{
${ }^{1}$ Weighted score:

Leaking Characteristics carries a weight of 3

Location carries a weight of 1

Toxicity carries a weight of 2
} 


\subsection{TANK W-8}

Tank W-8 is a 170,000-gal. gunite tank located in the Bethel Valley South Tank Farm. The underground tank was constructed in 1943 for the storage of LLLW.

\section{Tank Risk Characterization Summary}

Risk Characteristic

Leaking Characteristics

Inleaker

\section{Location}

South of Central Avenue

Toxicity

Primary Contaminant

${ }^{137} \mathrm{Cs}$
3(3)

3(1)

Score

$\mathbf{5}(2)$

22

\footnotetext{
${ }^{1}$ Weighted score:

Leaking Characteristics carries a weight of 3

Location carries a weight of 1

Toxicity carries a weight of 2
} 


\subsection{TANK W-9}

Tank W-9 is a 170,000-gal. gunite tank located in the Bethel Valley South Tank Farm. The underground tank was constructed in 1943 for the storage of LLLW.

Tank Risk Characterization Summary

Risk Characteristic

$\underline{\text { Score }}$

Leaking Characteristics

Inleaker

3(3)

Location

South of Central Avenue

3(1)

Toxicity

$\frac{\text { Primary Contaminant }}{{ }^{137} \mathrm{Cs}}$

4(2)

TOTAL SCORE ${ }^{1}$

${ }^{1}$ Weighted score:

Leaking Characteristics carries a weight of 3

Location carries a weight of 1

Toxicity carries a weight of 2 


\subsection{TANK W-10}

Tank W-10 is a 170,000 -gal. gunite tank located in the Bethel Valley South Tank Farm. The underground tank was constructed in 1943 for the storage of LLLW.

\section{Tank Risk Characterization Summary}

$\underline{\text { Risk Characteristic }}$

$\underline{\text { Score }}$

Leaking Characteristics

Inleaker

Location

South of Central Avenue

3(1)

Toxicity

$\frac{\text { Primary Contaminant }}{{ }^{137} \mathrm{Cs}}$

TOTAL SCORE ${ }^{1}$

${ }^{1}$ Weighted score:

Leaking Characteristics carries a weight of 3

Location carries a weight of 1

Toxicity carries a weight of 2 


\subsection{TANK W-11}

Tank W-11 is a 1500-gal. gunite tank located in the Bethel Valley South Tank Farm. The underground tank was constructed in 1943 to serve as a waste collection and monitoring tank for research laboratories in Building 3550.

Tank Risk Characterization Summary

Risk Characteristic

Leaking Characteristics

$$
\text { Inleaker }
$$

\section{Location}

South of Central Avenue

Toxicity

$\frac{\text { Primary Contaminant }}{{ }^{90} \mathrm{Sr}}$

TOTAL SCORE ${ }^{1}$ $\underline{\text { Score }}$

16

${ }^{1}$ Weighted score:

Leaking Characteristics carries a weight of 3

Location carries a weight of 1

Toxicity carries a weight of 2 


\subsection{TANK T1}

Tank T1 is a 15,000-gal. carbon steel tank located in Melton Valley at the Old Hydrofracture Facility. The underground tank was installed at the site in 1963 to store LLLW for mixing into grout for waste injection by hydrofracture.

\section{Tank Risk Characterization Summary}

\section{Risk Characteristic}

Leaking Characteristics

Inconclusive Leak Characterization (mild steel)

\section{Location}

Old Hydrofracture Facility Tank 5(1)

\section{Toxicity}

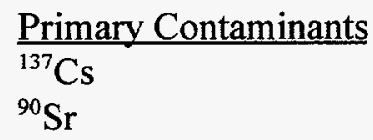

TOTAL SCORE ${ }^{1}$

1(3)

\section{$\underline{\text { Score }}$}

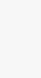




\subsection{TANK T2}

Tank T2 is a 15,000-gal. carbon steel tank located in Melton Valley at the Old Hydrofracture Facility. The underground tank was installed at the site in 1963 to store LLLW for mixing into grout for waste injection by hydrofracture.

\section{Tank Risk Characterization Summary}

Risk Characteristic

\section{Leaking Characteristics}

Inconclusive Leak Characterization (mild steel)

\section{Location}

Old Hydrofracture Facility Tank $5(1)$

Toxicity
Score

1(3) 


\subsection{TANK T3}

Tank T3 is a 25,000-gal. carbon steel tank located in Melton Valley at the Old Hydrofracture Facility. The underground tank was installed at the site in 1963 to store LLLW for mixing into grout for waste injection by hydrofracture.

Tank Risk Characterization Summary

Risk Characteristic

Score

Leaking Characteristics

Inconclusive Leak Characterization

(mild steel)

Location

Old Hydrofracture Facility Tank

Toxicity

$\frac{\text { Primary Contaminant }}{{ }^{137} \mathrm{Cs}}$

TOTAL SCORE ${ }^{1}$

16

'Weighted score:

Leaking Characteristics carries a weight of 3

Location carries a weight of 1

Toxicity carries a weight of 2 


\subsection{TANK T4}

Tank T4 is a 25,000-gal. carbon steel tank located in Melton Valley at the Old Hydrofracture Facility. The underground tank was installed at the site in 1963 to store LLLW for mixing into grout for waste injection by hydrofracture.

\section{Tank Risk Characterization Summary}

\section{Risk Characteristic}

Leaking Characteristics

Inconclusive Leak Characterization (mild steel)

\section{Location}

Old Hydrofracture Facility Tank

Toxicity

Primary Contaminant

${ }^{137} \mathrm{Cs}$ $\mathbf{5}(1)$

\section{Score}

1(3)$$
5(1)
$$

4(2)

TOTAL SCORE ${ }^{1}$

\footnotetext{
${ }^{1}$ Weighted score:

Leaking Characteristics carries a weight of 3

Location carries a weight of 1

Toxicity carries a weight of 2
} 


\subsection{TANK T9}

Tank T9 is a 25,000-gal. carbon steel tank located in Melton Valley at the Old Hydrofracture Facility. The underground tank was installed at the site in 1963 to store LLLW for mixing into grout for waste injection by hydrofracture.

\section{Tank Risk Characterization Summary}

\section{Risk Characteristic}

Leaking Characteristics

Inconclusive Leak Characterization (mild steel)

\section{Location}

Old Hydrofracture Facility Tank

$$
\text { 5(1) }
$$

Toxicity

$$
\begin{aligned}
& \text { Primary Contaminants } \\
& { }^{137} \mathrm{Cs} \\
& { }^{90} \mathrm{Sr}
\end{aligned}
$$

'Weighted score:

Leaking Characteristics carries a weight of 3

Location carries a weight of 1

Toxicity carries a weight of 2 


\subsection{TANK TH-1}

Tank TH-1 is a 2500-gal. stainless steel tank located in the Bethel Valley central laboratory area south of Building 3503. The underground tank was installed in 1948 and received waste from the thorium pilot plant project in Building 3503. Tank TH-1 was emptied in September 1992.

\section{Tank Risk Characterization Summary}

Risk Characteristic

\section{Leaking Characteristics}

Inconclusive Leak Characterization (stainless steel)

\section{Location}

$$
\text { South of Central Avenue }
$$

Toxicity

\section{$\underline{\text { Score }}$}

0

$3(1)$

0

\footnotetext{
${ }^{1}$ Weighted score:

Leaking Characteristics carries a weight of 3

Location carries a weight of 1

Toxicity carries a weight of 2
} 


\subsection{TANK TH-2}

Tank TH-2 is a 2400 -gal. stainless steel tank located in the Bethel Valley central laboratory area south of Building 3503. The underground tank was installed in 1952 and received waste from the thorium pilot plant project in Building 3503. Tank TH-2 was emptied in September 1992.

\section{Tank Risk Characterization Summary}

$\underline{\text { Risk Characteristic }}$

\section{Leaking Characteristics}

Inconclusive Leak Characterization

(stainless steel)

\section{Location}

South of Central Avenue

Toxicity

\section{$\underline{\text { Score }}$}

$\mathbf{0}$

3(1)

$\mathbf{0}$

TOTAL SCORE ${ }^{1}, 3$

${ }^{1}$ Weighted score:

Leaking Characteristics carries a weight of 3

Location carries a weight of 1

Toxicity carries a weight of 2 


\subsection{TANK TH-3}

Tank TH-3 is a 3300-gal. stainless steel tank located in the Bethel Valley central laboratory area south of Building 3503. The underground tank was installed in 1952 and received waste from the thorium pilot plant project in Building 3503. Tank TH-3 was emptied in September 1992.

\section{Tank Risk Characterization Summary}

\section{Risk Characteristic}

Leaking Characteristics

Inconclusive Leak Characterization (stainless steel)

\section{Location}

$$
\text { South of Central Avenue }
$$

Toxicity

\section{$\underline{\text { Score }}$}

$$
\mathbf{0}
$$

\section{0}

\footnotetext{
${ }^{1}$ Weighted score:
}

Leaking Characteristics carries a weight of 3

Location carries a weight of 1

Toxicity carries a weight of 2 


\subsection{TANK TH-4}

Tank TH-4 is a 14,000-gal. gunite tank located in the Bethel Valley central laboratory area south of Building 3503. The underground tank was installed in 1952 and received waste from the thorium and uranium pilot plant development projects in Building 3550 .

\section{Tank Risk Characterization Summary}

\section{Risk Characteristic}

\section{Leaking Characteristics}

Inconclusive Leak Characterization (concrete/gunite)

\section{Location}

South of Central Avenue

\section{Toxicity}

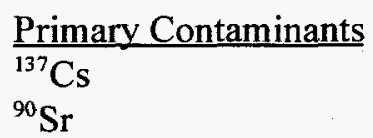

TOTAL SCORE ${ }^{1}$
3(1)

\section{Score}

2(3)

3(2)

15

${ }^{1}$ Weighted score:

Leaking Characteristics carries a weight of 3

Location carries a weight of 1

Toxicity carries a weight of 2 


\subsection{TANK WC-1}

Tank WC-1 is a 2150-gal. stainless steel tank located in the Isotopes Circle area of the Bethel Valley main laboratory area. The underground tank was installed in 1950 to collect LLLW from isotope production and development. Tank WC-1 was emptied in September 1992.

\section{Tank Risk Characterization Summary}

Risk Characteristic

\section{Leaking Characteristics}

Inconclusive Leak Characterization (stainless steel)

\section{Location}

$$
\text { North of Central Avenue }
$$

Toxicity

\section{Score}

0

2(1)

0

${ }^{1}$ Weighted score:

Leaking Characteristics carries a weight of 3

Location carries a weight of 1

Toxicity carries a weight of 2 


\subsection{TANK WC-15}

Tank WC-15 is a 1000-gal. stainless steel tank located in the 4500 area of the Bethel Valley main laboratory area. The underground tank was installed in 1951 to collect LLLW from the Building 4500 research laboratories.

Tank Risk Characterization Summary

$\underline{\text { Risk Characteristic }}$

$\underline{\text { Score }}$

\section{Leaking Characteristics}

Inconclusive Leak Characterization

$\mathbf{0}$

(stainless steel)

\section{Location}

South of Central Avenue

3(1)

Toxicity

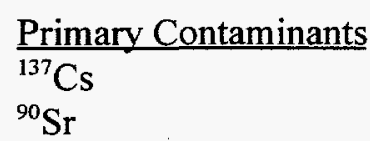

\footnotetext{
${ }^{1}$ Weighted score:

Leaking Characteristics carries a weight of 3

Location carries a weight of 1

Toxicity carries a weight of 2
} 


\subsection{TANK WC-17}

Tank WC-17 is a 1000-gal. stainless steel tank located in the 4500 area of the Bethel Valley main laboratory area. The underground tank was installed in 1951 to collect LLLW from the Building 4500 research laboratories. The tank was emptied and triple rinsed after the tank was identified as potentially outleaking. A videocamera inspection indicated two small holes in the bottom of the tank, with a very small amount of residual sludge that could not be removed by rinsing. Groundwater entered the tank and stabilized at a level of $\sim 400$ gal.

\section{Tank Risk Characterization Summary}

\section{$\underline{\text { Risk Characteristic }}$}

Leaking Characteristics

$$
\text { Small Outleaker }
$$

Location

$$
\text { South of Central Avenue }
$$

Toxicity

$$
3(1)
$$

\section{Score}

\section{0}

${ }^{1}$ Weighted score:

Leaking Characteristics carries a weight of 3

Location carries a weight of 1

Toxicity carries a weight of 2 


\subsection{TANK W-1}

Tank W-1 is a 4800 -gal. gunite tank located in the Bethel Valley North Tank Farm. The underground tank was constructed in 1943 and received LLLW from the Building 3019 radiochemical processing facility.

Tank Risk Characterization Summary

Risk Characteristic

\section{Leaking Characteristics}

Inconclusive Leak Characterization (concrete/gunite)

\section{Location}

North of Central Avenue

Toxicity

$\frac{\text { Primary Contaminant }}{{ }^{137} \mathrm{Cs}}$

TOTAL SCORE ${ }^{1}$
2(1)

Score

2(3)

2(2)

12

'Weighted score:

Leaking Characteristics carries a weight of 3

Location carries a weight of 1

Toxicity carries a weight of 2 


\subsection{TANK W-1A}

Tank W-1A is a 4000-gal. stainless steel tank located in the Bethel Valley North Tank Farm. The underground tank was installed in 1951 and received waste from the Radiochemical Processing Pilot Plant (Building 3019) and the High-level Radiochemical Analytical Laboratory (Buildings 3026 and 3019-B).

\section{Tank Risk Characterization Summary}

\section{Risk Characteristic}

Leaking Characteristics

$$
\text { Inleaker }
$$

\section{Location}

North of Central Avenue

Toxicity

Primary Contaminants
${ }^{137} \mathrm{Cs}$
${ }^{90} \mathrm{Sr}$
${ }^{238} \mathrm{Pu}$
${ }^{241} \mathrm{Am}$

\section{Score}

TOTAL SCORE ${ }^{1}$

${ }^{1}$ Weighted score:

Leaking Characteristics carries a weight of 3

Location carries a weight of 1

Toxicity carries a weight of 2 


\subsection{TANK W-2}

Tank W-2 is a 4800-gal. gunite tank located in the Bethel Valley North Tank Farm. The underground tank was constructed in 1943 and received LLLW from the Building 3019 radiochemical processing facility.

\section{Tank Risk Characterization Summary}

Risk Characteristic

$\underline{\text { Score }}$

\section{Leaking Characteristics}

Inconclusive Leak Characterization (concrete/gunite)

\section{Location}

$$
\text { North of Central Avenue }
$$

\section{Toxicity}

$\frac{\text { Primary Contaminant }}{{ }^{137} \mathrm{Cs}}$

TOTAL SCORE ${ }^{1}$
2(3)

$$
\text { 2(2) }
$$

${ }^{1}$ Weighted score:

Leaking Characteristics carries a weight of 3

Location carries a weight of 1

Toxicity carries a weight of 2 


\subsection{TANK W-3}

Tank W-3 is a 42,500-gal. gunite tank located in the Bethel Valley North Tank Farm. The underground tank was constructed in 1943 and received LLLW from the Building 3019 radiochemical processing facility.

\section{Tank Risk Characterization Summary}

$\underline{\text { Risk Characteristic }}$

Score

Leaking Characteristics

Inleaker

Location

North of Central Avenue

2(1)

Toxicity

$\frac{\text { Primary Contaminant }}{{ }^{137} \mathrm{Cs}}$

4(2)

TOTAL SCORE ${ }^{1}$

'Weighted score:

Leaking Characteristics carries a weight of 3

Location carries a weight of 1

Toxicity carries a weight of 2 


\subsection{TANK W-4}

Tank W-4 is a 42,500-gal. gunite tank located in the Bethel Valley North Tank Farm. The underground tank was constructed in 1943 and received LLLW from the Building 3019 radiochemical processing facility.

\section{Tank Risk Characterization Summary}

Risk Characteristic

Score

Leaking Characteristics

Inleaker $\quad \dot{3}(3)$

Location

North of Central Avenue 2(1)

Toxicity

Primary Contaminants $\quad$ 4(2)

${ }^{137} \mathrm{Cs}$

${ }^{90} \mathrm{Sr}$

${ }^{1}$ Weighted score:

Leaking Characteristics carries a weight of 3

Location carries a weight of 1

Toxicity carries a weight of 2 


\subsection{TANK W-13}

Tank W-13 is a 2000 -gal. stainless steel tank located in the Bethel Valley North Tank Farm. The underground tank was constructed in 1945 and received waste from the Radiochemical Processing Facility (Building 3019) and from recovery of fission products. Tank W-13 was emptied in September 1992.

\section{Tank Risk Characterization Summary}

Risk Characteristic

$\underline{\text { Score }}$

Leaking Characteristics

Inconclusive Leak Characterization

0 (stainless steel)

\section{Location}

North of Central Avenue 2(1)

Toxicity

0

TOTAL SCORE ${ }^{1}$

'Weighted score:

Leaking Characteristics carries a weight of 3

Location carries a weight of 1

Toxicity carries a weight of 2 


\subsection{TANK W-14}

Tank W-14 is a 2000-gal. stainless steel tank located in the Bethel Valley North Tank Farm. The underground tank was constructed in 1945 and received waste from the Radiochemical Processing Facility (Building 3019) and from recovery of fission products. Tank W-14 was emptied in September 1992.

\section{Tank Risk Characterization Summary}

Risk Characteristic

\section{Leaking Characteristics}

Inconclusive Leak Characterization (stainless steel)

\section{Location}

North of Central Avenue

Toxicity $\underline{\text { Score }}$

0

2(1)

0

\footnotetext{
${ }^{1}$ Weighted score:

Leaking Characteristics carries a weight of 3

Location carries a weight of 1

Toxicity carries a weight of 2
} 


\subsection{TANK W-15}

Tank W-15 is a 2000-gal. stainless steel tank located in the Bethel Valley North Tank Farm. The underground tank was constructed in 1945 and received waste from the Radiochemical Processing Facility (Building 3019) and from recovery of fission products.

\section{Tank Risk Characterization Summary}

\section{Risk Characteristic}

Leaking Characteristics

Inconclusive Leak Characterization (stainless steel)

\section{Location}

North of Central Avenue

Toxicity 2(1)

\section{$\underline{\text { Score }}$}

0

$\mathbf{0}$

TOTAL SCORE ${ }^{1}$

\footnotetext{
'Weighted score:

Leaking Characteristics carries a weight of 3

Location carries a weight of 1

Toxicity carries a weight of 2
} 


\subsection{TANK 7560}

Tank 7560 is a 1000-gal. stainless steel tank located in Melton Valley. The underground tank was installed in 1957 and was originally used as a waste tank for the Homogeneous Reactor Experiment (HRE) and later used as the clean vapor condensate tank for HRE-2. The tank is empty.

\section{Tank Risk Characterization Summary}

$\underline{\text { Risk Characteristic }}$

Score

\section{Leaking Characteristics}

Inconclusive Leak Characterization

0

(stainless steel)

\section{Location}

HRE Tank

Toxicity
1(1)

0

1

${ }^{1}$ Weighted score:

Leaking Characteristics carries a weight of 3

Location carries a weight of 1

Toxicity carries a weight of 2 


\subsection{TANK 7562}

Tank 7562 is a 12,000-gal. stainless steel tank located in Melton Valley. The underground tank was installed in 1957 and was used as a waste tank for the Homogenous Reactor Experiment (HRE). Tank 7562 was isolated from its piping in 1996 and remediated in-place by filling the tank shell with flowable fill (grout) in 1997. 


\subsection{TANK T-30}

Tank T-30 is an 825-gal. stainless steel tank located south of Building 4507 in the Bethel Valley main laboratory area. The underground tank was installed in 1961 and was used to store radioactive materials for the Curium Recovery Facility. Tank T-30 was remediated in place by filling the tank shell with flowable fill (grout) in 1996. 


\subsection{TANK W-19}

Tank W-19 is a 2250-gal. stainless steel tank located in Bethel Valley near the South Tank Farm east of Building 3505. The underground tank was installed in 1955 and was used to collect waste produced from recovery and reprocessing of uranium and other nuclear material from the Metal Recovery Facility in Building 3505. The tank is empty.

\section{Tank Risk Characterization Summary}

$\underline{\text { Risk Characteristic }}$

$\underline{\text { Score }}$

Leaking Characteristics

Inconclusive Leak Characterization (stainless steel)

\section{Location}

South of Central Avenue

3(1)

Toxicity

TOTAL SCORE $^{1} \quad 3$

'Weighted score:

Leaking Characteristics carries a weight of 3

Location carries a weight of 1

Toxicity carries a weight of 2 


\subsection{TANK W-20}

Tank W-20 is a 2250-gal. stainless steel tank located in Bethel Valley near the South Tank Farm east of Building 3503. The underground tank was installed in 1955 and was used to collect waste produced from recovery and reprocessing of uranium and other nuclear material from the Metal Recovery Facility in Building 3505. The tank is empty.

\section{Tank Risk Characterization Summary}

Risk Characteristic

\section{$\underline{\text { Score }}$}

\section{Leaking Characteristics}

Inconclusive Leak Characterization (stainless steel)

\section{Location}

South of Central Avenue 3(1)

Toxicity

TOTAL SCORE
0

0

3

'Weighted score:

Leaking Characteristics carries a weight of 3

Location carries a weight of 1

Toxicity carries a weight of 2 
Section 4/page 36 of 62 Risk Characterization Data Manual for ORNL Category D Inactive LLLW Tanks

\subsection{TANK 3001-B}

Tank 3001-B was removed in October 1995. 


\subsection{TANK 3003-A}

Tank 3003-A is a 16,000-gal. concrete tank located south of Building 3003 and north of Hillside and Central avenues in the Bethel Valley main laboratory area. The tank was constructed in 1943 and collected drainage from three cells and a stack in Building 3003. Tank 3003-A is scheduled to be emptied in September 1993.

\section{Tank Risk Characterization Summary}

Risk Characteristic

\section{Leaking Characteristics}

Inconclusive Leak Characterization (concrete)

\section{Location}

North of Central Avenue

Toxicity

$$
\begin{aligned}
& \frac{\text { Primary Contaminants }}{{ }^{60} \mathrm{Co}} \\
& { }^{137} \mathrm{Cs}
\end{aligned}
$$

$$
\text { 2(1) }
$$

$\underline{\text { Score }}$

${ }^{1}$ Weighted score:

Leaking Characteristics carries a weight of 3

Location carries a weight of 1

Toxicity carries a weight of 2 
Section 4/page 38 of 62 Risk Characterization Data Manual for ORNL Category D Inactive LLLW Tanks

\subsection{TANK 3004-B}

Tank 3004-B was removed in August 1995. 


\subsection{TANK 3013}

Tank 3013 was isolated from its piping system and filled with flowable fill (grout) in August 1995. 


\subsection{TANK H-209}

Tank H-209 is a 2500-gal. (best estimate) stainless steel tank located west of Building 3517 and Central Avenue and north of White Oak Avenue in the Bethel Valley main laboratory area. The tank was installed in 1961 and held condensate and floor drainage from Building 3517. Tank H-209 was remediated in place by filling the tank shell with flowable fill (grout) in 1996. 


\subsection{TANK 7503-A}

Tank 7503-A is an 11,000-gal. stainless steel tank in an in-ground vault northwest of Building 7503 in the Melton Valley area. The tank was installed in 1962 and was a waste holding tank for the Molten Salt Reactor Experiment. The tank is empty.

\section{Tank Risk Characterization Summary}

Risk Characteristic

\section{Leaking Characteristics}

Inconclusive Leak Characterization (stainless steel)

\section{Location}

HRE Tanks

Toxicity

\section{Score}

$\mathbf{0}$

1(1)

0

TOTAL SCORE ${ }^{1}$

${ }^{1}$ Weighted score:

Leaking Characteristics carries a weight of 3

Location carries a weight of 1

Toxicity carries a weight of 2 


\subsection{TANK 3001-S}

Tank 3001-S was not sampled or characterized because a field investigation was unable to verify the tank's existence, which had been postulated based on the existence of some design drawings of the tank. 


\subsection{TANK 3002-A}

Tank $3002-\mathrm{A}$ is a 1600 -gal. stainless steel tank located in a below-grade vault south of Filter House 3002 . The tank was installed in 1943 to collect condensate from the filter house that served the Graphite Reactor. The filter house was declared surplus and the tank was removed from service by 1989 .

\section{Tank Risk Characterization Summary}

Risk Characteristic

$\underline{\text { Score }}$

\section{Leaking Characteristics}

Inleaker

$$
\text { 3(3) }
$$

Location

North of Central Avenue

Toxicity
2(1)

$\mathbf{0}$

11

${ }^{1}$ Weighted score:

Leaking Characteristics carries a weight of 3

Location carries a weight of 1

Toxicity carries a weight of 2 


\subsection{TANK 4501-P}

Tank 4501-P is a 100-gal. stainless steel tank located in the Bethel Valley, 4500 Area. The tank was used to store waste from the plutonium recovery loop experiment and other waste from experiments in Building 4501. The data of installation for Tank 4501-P is unknown. The tank was remediated in place by filling the tank shell with flowable fill (grout) in 1996. 


\subsection{TANK S-424}

Tank S-424 is a 500-gal. stainless steel located in an in-ground vault south of Central Avenue. The tank was installed in 1955 and was used to collect highly corrosive chloride-bearing supernate from a precipitation operation.

\section{Tank Risk Characterization Summary}

Risk Characteristic

$\underline{\text { Score }}$

\section{Leaking Characteristics}

Inconclusive Leak Characterization

0

(stainless steel)

\section{Location}

South of Central Avenue 3(1)

Toxicity

0

TOTAL SCORE ${ }^{1}$

3

${ }^{1}$ Weighted score:

Leaking Characteristics carries a weight of 3

Location carries a weight of 1

Toxicity carries a weight of 2 


\subsection{TANK T-14}

Tank T-14 is a 48,500-gal. concrete tank located in the Melton Valley Area. The tank was installed in 1979 and was used as an overflow emergency waste tank for the Hydrofracture Facility.

\section{Tank Risk Characterization Summary}

Risk Characteristic

\section{Leaking Characteristics}

Inconclusive Leak Characterization (concrete)

\section{Location}

Old Hydrofracture Facility Tank

Toxicity $\underline{\text { Score }}$

2(3)

$5(1)$

0

TOTAL SCORE ${ }^{1}$

${ }^{1}$ Weighted score:

Leaking Characteristics carries a weight of 3

Location carries a weight of 1

Toxicity carries a weight of 2 


\subsection{TANK W-1I}

Tank W-1I is a 500-gal. stainless steel tank located in Bethel Valley under the floor slab of the east airlock of Building 3028 and north of Central Avenue. The tank was installed in 1959 and was used to collect and monitor process liquid waste from isotopes production and development laboratories in Buildings 3038, 3028, 3030, 3032, 3033, 3047; the filter in Building 3110; the stack in Building 3039; and the scrubber in Building 3092.

\section{Tank Risk Characterization Summary}

Risk Characteristic

Score

\section{Leaking Characteristics}

Inconclusive Leak Characterization

$\mathbf{0}$

(stainless steel)

\section{Location}

North of Central Avenue

Toxicity

$\mathbf{0}$ 


\subsection{TANK WC-4}

Tank WC-4 is a 1700-gal. stainless steel tank located in Bethel Valley, north of Central Avenue. The tank was installed in 1944 and was used as a waste tank for Building 3026 for waste primarily generated from the Roll Up Process, which involved dissolving uranium targets and extracting isotopes.

\section{Tank Risk Characterization Summary}

\section{$\underline{\text { Risk Characteristic }}$}

\section{Leaking Characteristics}

$$
\text { Inleaker }
$$

\section{Location}

North of Central Avenue

2(1)

\section{Toxicity}

$$
\frac{\text { Primary Contaminant }}{{ }^{137} \mathrm{Cs}}
$$

${ }^{1}$ Weighted score:

Leaking Characteristics carries a weight of 3

Location carries a weight of 1

Toxicity carries a weight of 2 


\subsection{TANK W-17}

Tank W-17 is a 1000-gal. stainless steel tank located in Bethel Valley west of 4th Street and south of Central Avenue near the South Tank Farm. The tank was installed in 1951 and served as a waste tank for isotope production in Building 3026.

\section{Tank Risk Characterization Summary}

$\underline{\text { Risk Characteristic }}$

\section{Leaking Characteristics}

Indeterminate Leak Characterization (stainless steel)

\section{Location}

South of Central Avenue

\section{Toxicity}

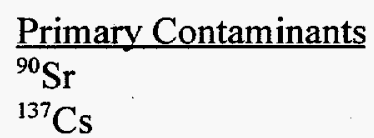

TOTAL SCORE ${ }^{1}$

$$
3(1)
$$

\section{0

\section{$\underline{\text { Score }}$}

0

${ }^{1}$ Weighted score:

Leaking Characteristics carries a weight of 3

Location carries a weight of 1

Toxicity carries a weight of 2 


\subsection{TANK W-18}

Tank W-18 is a 1000-gal. stainless steel tank located in Bethel Valley west of 4th Street and south of Central Avenue near the South Tank Farm. The tank was installed in 1951 and served as a waste tank for isotope production in Building 3026.

\section{Tank Risk Characterization Summary}

\section{Risk Characteristic}

\section{Leaking Characteristics}

Inleaker

Location

South of Central Avenue

3(1)

Toxicity

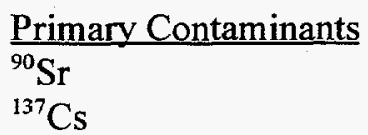

TOTAL SCORE ${ }^{1}$

3(3)

\section{$\underline{\text { Score }}$}

)

\footnotetext{
${ }^{1}$ Weighted score:

Leaking Characteristics carries a weight of 3

Location carries a weight of 1

Toxicity carries a weight of 2
} 


\subsection{TANK WC-5}

Tank WC-5 is a 1000-gal. stainless steel tank located in Bethel Valley and south of Central Avenue. The tank was installed in 1952 and received waste from development projects in Buildings 3508,3541 , and 3592 . Tank WC-5 was remediated by filling the tank shell with flowable fill (grout) in 1997. 


\subsection{TANK WC-6}

Tank WC-6 is a 500-gal. stainless steel tank located in Bethel Valley and south of Central Avenue. The tank was installed in 1952 and received waste from development projects in Buildings 3508,3541 , and 3592 . Tank WC-6 was remediated by filling the tank shell with flowable fill (grout) in 1997. 


\subsection{TANK WC-8}

Tank WC-8 is a 1000-gal. stainless steel tank located in Bethel Valley and south of Central Avenue. The tank was installed in 1952 and received waste from development projects in Buildings 3508,3541 , and 3592 . Tank WC-8 was remediated by filling the tank shell with flowable fill (grout) in 1997. 


\subsection{TANK WC-11}

Tank WC-11 is a 4000-gal. stainless steel tank located south of Building 3587 and Central Avenue. The tank was installed in 1951 and was used as a waste tank for the 4500 complex.

\section{Tank Risk Characterization Summary}

Risk Characteristic

Leaking Characteristics

Inleaker

Location

South of Central Avenue

Toxicity

$\frac{\text { Primary Contaminant }}{{ }^{137} \mathrm{Cs}}$

TOTAL SCORE ${ }^{1}$
3(3)

3(1)

3(2)

$\underline{\text { Score }}$

18

${ }^{1}$ Weighted score:

Leaking Characteristics carries a weight of 3

Location carries a weight of 1

Toxicity carries a weight of 2 


\subsection{TANK WC-12}

Tank WC-12 is a 700-gal. stainless steel tank located south of Building 3587 and Central Avenue. The tank was installed in 1947 and was used as a waste tank for the 4500 complex.

\section{Tank Risk Characterization Summary}

\section{Risk Characteristic}

\section{Leaking Characteristics}

Inleaker

3(3)

Location

South of Central Avenue

3(1)

Toxicity

$$
\text { Primary Contaminant }
$$$$
{ }^{137} \mathrm{Cs}
$$

\section{Score}




\subsection{TANK WC-13}

Tank WC-13 is a 1000-gal. stainless steel tank located south of Building 3587 and Central Avenue. The tank was installed in 1951 and was used as a waste tank for the 4500 complex.

\section{Tank Risk Characterization Summary}

Risk Characteristic

\section{Leaking Characteristics}

$$
\text { Inleaker }
$$

\section{Location}

South of Central Avenue

Toxicity

$\frac{\text { Primary Contaminant }}{{ }^{137} \mathrm{Cs}}$

TOTAL SCORE
3(1)

$\underline{\text { Score }}$

18

${ }^{1}$ Weighted score:

Leaking Characteristics carries a weight of 3

Location carries a weight of 1

Toxicity carries a weight of 2 


\subsection{TANK WC-14}

Tank WC-14 is a 1000-gal. stainless steel tank located south of Building 3587 and Central Avenue. The tank was installed in 1951 and was used as a waste tank for the 4500 complex.

\section{Tank Risk Characterization Summary}

Risk Characteristic

\section{Leaking Characteristics}

Inleaker

Location

South of Central Avenue

Toxicity

Primary Contaminant ${ }^{137} \mathrm{Cs}$
3(3)

3(1)

Score

3(2)

18

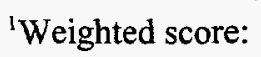

Leaking Characteristics carries a weight of 3

Location carries a weight of 1

Toxicity carries a weight of 2 
Section 4/page 58 of 62 Risk Characterization Data Manual for ORNL Category D Inactive LLLW Tanks

\subsection{TANK LA-104}

Tank LA-104 was removed in February 1996. 


\subsection{TANK WC-7}

Tank WC-7 is a 1100-gal stainless steel tank located west of Bldg. 3504. The tank was installed in 1951 and received wastes from geosciences projects in Bldg. 3504. Tank WC-7 was remediated by filling the tank shell with flowable fill (grout) in 1996. 


\subsection{TANK 2026A}

Tank 2026A is a 700-gal. vertical tank located inside an in-ground concrete vault southeast of Building 2026. The tank is constructed of Hastelloy $\mathrm{C}$ with stainless steel top head and piping. The tank was installed in 1962 and received radioactive and chemical wastes from processes involving radioactive sample analysis in Building 2026. Tank 2026A was removed from active service March $31,1996$.

\section{Tank Risk Characterization Summary}

\section{Risk Characteristic}

\section{Leaking Characteristics}

Inleaker

\section{Location}

North of Central Avenue

Toxicity

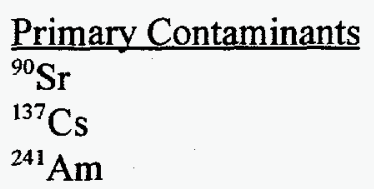

TOTAL SCORE
3(3)

2(1)

$\underline{\text { Score }}$

15

${ }^{1}$ Weighted score:

Leaking Characteristics carries a weight of 3

Location carries a weight of 1

Toxicity carries a weight of 2 


\subsection{TANK WC-19}

Tank WC-19 is a 2000-gal. Type 347 stainless steel tank located north of Building 3047 near Hillside Drive. The tank was installed in 1955 and received waste from buildings in the 3001 (Old Graphite Reactor) and 3042 (Oak Ridge Research Reactor) areas. The waste was primarily from the regeneration and back washing of the demineralizers for the reactors and storage canal, and condensate from ventilation systems. The liquid contents of tank WC-19 were jetted to the LLLW system and the tank was removed from active service September 30, 1996.

\section{Tank Risk Characterization Summary}

Risk Characteristic

\section{Leaking Characteristics}

Inleaker

\section{Location}

North of Central Avenue

\section{Toxicity}

Empty tank

$$
\text { 2(1) }
$$

\section{$\underline{\text { Score }}$}

$$
\mathbf{0}(2)
$$

TOTAL SCORE ${ }^{1}$

\footnotetext{
'Weighted score:

Leaking Characteristics carries a weight of 3

Location carries a weight of 1

Toxicity carries a weight of 2
} 


\subsection{TANK W-12}

Tank W-12 is a 700-gal. stainless steel tank located in Bethel Valley South Tank Farm south of Central Avenue. The tank was installed in 1947 and was originally used to service Building $706 \mathrm{~A}$, which was subsequently decommissioned. In the past, the tank has also been used to service Building 3517 and collected wastes from the sumps of Tanks W-19 and W-20. More recently, the tank collected LLLW from the High Radiation Examination Laboratory (Building 3525) via Tanks F-201 and F-501.

Tank Risk Characterization Summary

Risk Characteristic

\section{Leaking Characteristics}

Inconclusive Leak Characterization ${ }^{1}$ (stainless steel)

\section{Location}

South of Central Avenue

3(1)

Toxicity

Primary Contaminant
${ }^{137} \mathrm{Cs}$
${ }^{192} \mathrm{Ir}$

TOTAL SCORE ${ }^{2}$

0

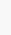

Score 


\section{REFERENCES}

1. V. Chidambariah, C.C. Travis, J.R. Trabalka, and J.K. Thomas, Risk-Based Prioritization for the Interim Remediation of Inactive Low-Level Liquid Radioactive Waste Underground Storage Tanks at Oak Ridge National Laboratory, Oak Ridge, Tennessee, ORNL/ER-84, Martin Marietta Energy Systems, Inc., 1992.

2. J.W. Autrey, D.A. Costanzo, W.H. Griest, L.L. Kaiser, J.M. Keller, C.E. Nix, and B.A. Tomkins, Sampling and Analysis of the Inactive Waste Storage Tank Contents at ORNL, ORNL/ER-13, Martin Marietta Energy Systems, Inc., 1990.

3. J.W. Autrey J.M. Keller, W.H. Griest, J.L. Botts, R.L. Schenley, and M.A. Sipe, Sampling and Analysis of the Inactive Waste Tanks TH-2, WC-1, and WC-15, ORNL/ER-19, Martin Marietta Energy Systems, Inc., 1990.

4. Bechtel National, Inc., Leak Testing Data Manual for Inactive LLLW Storage Tanks at Oak Ridge National Laboratory, Oak Ridge, Tennessee, ORNL/ER/Sub/87-99053/43, Martin Marietta Energy Systems, Inc., 1992.

5. United States Department of Energy, Federal Facility Agreement Plans and Schedules for Liquid Low-Level Radioactive Waste Tank Systems at Oak Ridge National Laboratory, Oak Ridge, Tennessee, DOE/OR/01-1135\&D2, Waste Management and Remedial Action Division, ORNL, Martin Marietta Energy Systems, Inc., 1993.

6. United States Department of Energy, Remediation Schedule for Inactive Liquid Low-Level Waste Storage Tanks at Oak Ridge National Laboratory, Oak Ridge, Tennessee. DOE/OR/011138\&D1. Prepared by H\&R Technical Associates, Inc., for Oak Ridge National Laboratory, Martin Marietta Energy Systems, Inc. 1993.

7. United States Department of Energy, Waste Characterization Data Manual for the Inactive Liquid Low-Level Waste Tank Systems at Oak Ridge National Laboratory, Oak Ridge, Tennessee. DOE/OR/01-1159\&D1. Prepared by Bechtel National, Inc./CH2M Hill for Oak Ridge National Laboratory, Martin Marietta Energy Systems, Inc. 1993. 


\section{DISTRIBUTION}

1. M. R. Ally

2. L. V. Asplund (U)

3. R. E. Bell

3. W. R. Clark

4. J. T. Etheridge

5. T. L. Hatmaker

6. L. Holder

7. L. D. Hyde

8. L. L. Kaiser

9. T. M. Koepp (U)

10. C. W. McGinn

11. D. A. May

12. C. E. Mulkey

13. P. T. Owen (U)

14. M. R. Peet

15. L. B. Raulston (U)

16. S. T. Rudell

17. C. B. Scott

18. M. B. Sears

19. R. C. Stewart

20. M. L. Whitehead

21. Central Research Library (U)

22. File-EMEF DMC-RC

23. R. C. Sleeman, Director, Remediation Management, DOE Oak Ridge Operations Office of Environmental Management, P.O. Box 2001, Oak Ridge, TN 37831-8541

24. R. C. Mitchell, H\&R Technical Associates, Inc., 151 LaFayette Drive, Suite 220, P.O. Box 4159, Oak Ridge, Tennessee 37831-4159 